\title{
Synthesis of planar chiral ferrocenyl sulfides and evaluation as catalysts for the asymmetric epoxidation of aldehydes
}

\author{
Stéphanie Minière, Vincent Reboul, and Patrick Metzner*
}

Laboratoire de Chimie Moléculaire et Thio-organique (UMR CNRS 6507), ENSICAEN-

Université, 6, boulevard du Maréchal Juin, 14050 Caen, France

E-mail: metzner@ensicaen.fr

The paper is dedicated to Prof. S. Swaminathan on the occasion of his $80^{\text {th }}$ birthday

(received 29 Oct 04; accepted 06 Jan 05; published on the web 12 Jan 05)

\begin{abstract}
New ferrocenyl sulfides, exhibiting planar chirality, have been prepared. They incorporate various heteroatom groups, and in some cases central chirality (sulfur or carbon). They were evaluated as catalysts for the asymmetric epoxidation of aldehydes via sulfonium ylides. A onepot reaction has been achieved, involving addition of benzaldehyde, benzyl bromide, 20\% molar equivalent of the ferrocenyl sulfide, sodium iodide in a mixture of tert-butanol and water. Good yields of stilbene oxide were obtained, with enantiomeric excesses up to $53 \%$.
\end{abstract}

Keywords: Ferrocenes, planar chirality, sulfides, sulfur ylides, epoxidation, oxiranes

\section{Introduction}

The need for new catalysts and ligands for asymmetric synthesis continues to grow. ${ }^{1-7}$ Organocatalysis $^{8,9}$ brings specific challenges in terms of kinetic rates and efficiency. We are interested in the synthesis of oxiranes by the Johnson-Corey reaction of sulfur ylides with aldehydes. $^{10-12}$ We have recently reported $^{13-17}$ an aliphatic $C_{2}$ symmetric sulfide, 2,5-dimethylthiolane, as a chiral auxiliary used in a catalytic amount for this reaction, which could be performed easily with yields and enantiomeric excesses around 90\% (Scheme 1).

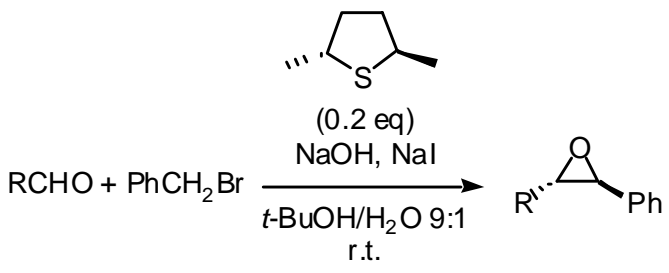

\section{Scheme 1}


Despite these achievements, this reaction suffers from some limitations: rates are moderate, and the scope of the substrates is not yet large enough. Therefore, we have wished to explore novel sulfides, which might fulfill these challenges. Among other structures, we have recently investigated ferrocenyl sulfides ${ }^{18}$ of two types (Figure 1): compounds A bearing an orthosubstituent (or their enantiomers), and derivatives $\mathbf{B}$, incorporating a ring fused with one of the cyclopentadienyl rings. We have just reported our results ${ }^{19}$ with compounds B (e.e.'s up to $94 \%$ ) and wish to report now our investigation of A ferrocenyl sulfides. We will discuss first the synthesis of the novel sulfides and we will then describe the evaluation of their activity as catalysts for the asymmetric epoxidation of benzaldehyde.

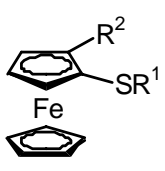

A

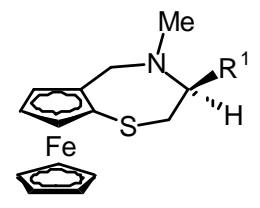

B

Figure 1

\section{Results and Discussion}

Having shown previously ${ }^{18}$ with one example of type $\mathbf{A}$ (its enantiomer bearing $\mathrm{R}^{1}=t$-Bu and $\mathrm{R}^{2}=\mathrm{NHTs}$ ) that planar chirality can lead to asymmetric epoxidation (e.e. 67\%), we have wished to screen a variety of sulfides (Figure 2), bearing in most cases a $t$-butylsulfanyl group connected directly to one of the cyclopentadienyl ring of ferrocene. In order to investigate steric and electronic factors, we have placed in the ortho position, a variety of heteroatomic groups: a trimethylsilyl (5a), a methylsulfanyl (5b), a stereogenic alkylsulfinyl (4b, 4c), a trialkylstannyl (5d, 5e). In a second series, we have introduced a hindered alkyl chain (5f), an aryl group (5g), or a chain bearing a stereogenic carbon and a coordinating nitrogen atom $(\mathbf{6 a}, \mathbf{6 b})$.

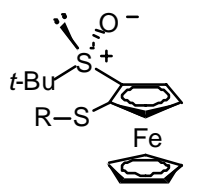

4b, $\mathrm{R}=\mathrm{Me}$

$4 c, R=C y$

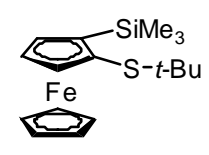

$5 a$

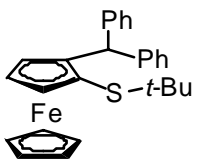

$5 f$

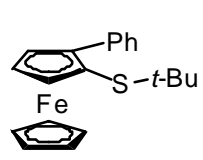

$5 g$

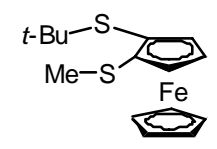

$5 \mathbf{b}$

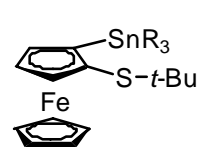

5d, $\mathrm{R}=\mathrm{Me}$

5e, $\mathrm{R}=n-\mathrm{Bu}$

Figure 2

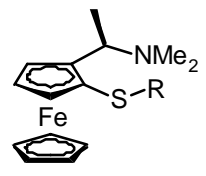

6a, $\mathrm{R}=\mathrm{Me}$ 6b, $R=C y$ 


\section{Synthesis of planar chiral ferrocenyl sulfides}

Our starting materials were ferrocenes $\mathbf{1}, 2$, and 3 bearing respectively cyclohexylsulfinyl, t-butylsulfinyl and 1-(N,N-dimethylamino)ethyl groups (Figure 3).

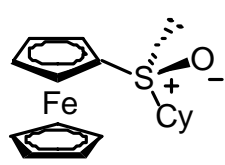

(S)-1

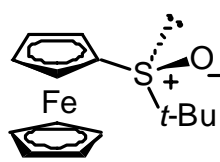

$(S)-2$

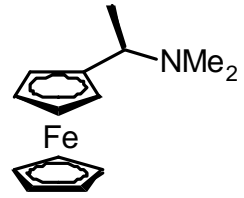

$(R)-3$

\section{Figure 3}

Our synthesis of unreported cyclohexylsulfinylferrocene 1 was motivated by the need of a substituent on sulfur that would be less hindered than a t-butyl group. Indeed, we found that the epoxidation reaction can be strongly retarded by steric effects. On the other hand, these effects are also necessary for the asymmetric induction. Therefore, we thought that a good compromise for the group on sulfur would be a cyclohexyl, or alternatively an isopropyl. In order to prepare sulfoxide 1, we planned to use the Andersen reaction of ferrocenyllithium with (S)-DAGcyclohexanesulfinate, a reagent, which we have used in another context. ${ }^{20,21}$ It was prepared on a large scale, using the remarkable and efficient Khiar-Alcudia dynamic kinetic resolution, ${ }^{22,23}$ based on $D$-glucose as a chiral source and involving the esterification reaction of a racemic alkanesulfinyl chloride. Our first attempts to synthesize (S)-1 were disappointing. As the DAG sulfinate was less reactive than a disulfide, we carried out the reaction of ferrocenyllithium from $0^{\circ} \mathrm{C}$ to room temperature. Cyclohexylsulfinylferrocene was isolated in $66 \%$ yield, with $29 \%$ recovery of ferrocene, but enantioselective HPLC revealed that the product was racemic. This may be explained ${ }^{24}$ by attack of unreacted ferrocenyllithium with the expected sulfoxide $(S)$ configuration, leading to racemization though a hypervalent intermediate. To overcome this undesired process, we have carried out the reaction a $-78^{\circ} \mathrm{C}$. We obtained sulfoxide 1 in a yield of $39 \%$ and an enantiomeric excess of $95 \%$ (Scheme 2). This novel sulfoxide is thus available for further studies.

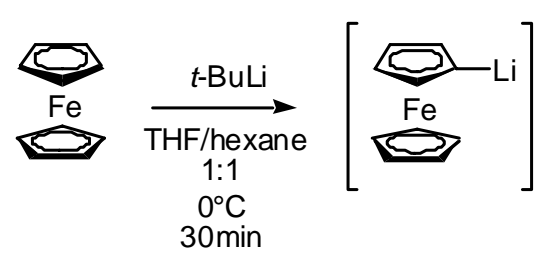

$30 \mathrm{~min}$

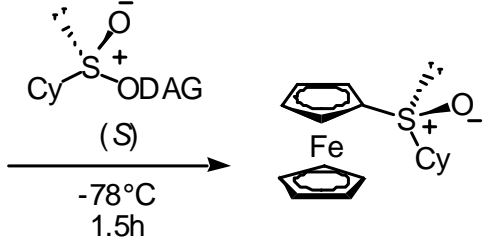

(S)-1, 39\% e.e. $95 \%$

\section{Scheme 2}


$t$-Butylsulfoxide 2 can be prepared by enantioselective oxidation of the corresponding sulfide, ${ }^{25}$ or by the Andersen reaction of ferrocenyllithium with an enantiopure thiosulfinate. ${ }^{26,27}$ We have used the latter method, which was reported by Carretero and his group (Scheme 3). The first step is a facile preparation ${ }^{28,29}$ of $(S)$-t-butyl $t$-butanethiosulfinate in $95 \%$ enantiomeric excess, according to Ellman et al. It involves oxidation of $t$-butyldisulfide by hydrogen peroxide with a catalytic amount $(0.5 \%)$ of $\mathrm{VO}(\mathrm{acac})_{2}$ and an hydroxyimine derived from $(1 S, 2 R)-1$ amino-2-indanol $(0.52 \%)$. For the second step, we have preferred to prepare ferrocenyllithium by deprotonation of ferrocene with 2 equiv. of $t$ - BuLi and 0.12 equiv. of $t$-BuOK in THF. ${ }^{30,31}$ Subsequent reaction of the cannulated metallated species with the thiosulfinate furnished sulfoxide 2 in $68 \%$ yield (e.e. $95-100 \%$ ).

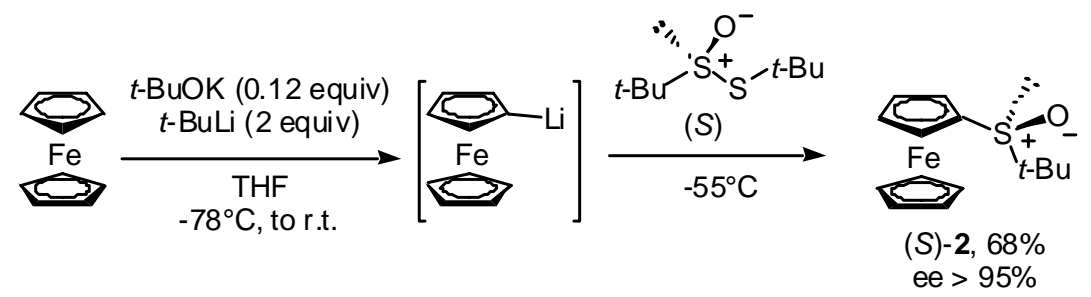

\section{Scheme 3}

Compound 3 (Figure 3) is commercially available and can also be easily resolved with tartaric acid. ${ }^{32,33}$ Amine 3 and sulfoxide 2 have been reported ${ }^{25,32}$ to undergo ortho-deprotonation with high diastereoselectivity in presence of a strong base. We have used this property to synthesize compounds 4 and 6 (Figure 2). Deprotonation of the amine 3 was effected by $n$-BuLi under conditions reported by Ugi and his group. ${ }^{32}$ The metallated ferrocene was sulfanylated by dimethyl- or dicyclohexyl- disulfides to lead to aminosulfides $\mathbf{6} \mathbf{a}^{32}$ and $\mathbf{6 b}$. Very modest yields of pure materials, respectively 21 and $38 \%$, were obtained as a result of the crystallization required for purification.

In the sulfoxide series, ortho-deprotonation of 2 was effected by $t$-butyllithium, according to literature. ${ }^{27} \mathrm{~A}$ variety of electrophiles were submitted to the resulting lithium t-butylsulfinylferrocene 7 (Scheme 4). Introduction of a trialkylsilyl moiety was possible with trimethylchlorosilane from $-78^{\circ} \mathrm{C}$ to ambient temperature, providing ferrocene $4 a$ in $88 \%$ yield. Reaction with dimethyl or dicyclohexyl disulfides, under similar conditions, afforded excellent yields of methyl- and cyclohexylsulfanylferrocenes $\mathbf{4 b}$ and $\mathbf{4 c}$, respectively $98 \%$ and $94 \%$. Stannylation of anion 7 was effective with both tri-n-butyl- and trimethylchlorostannane in respective quantitative (crude, unstable to chromatography) and $90 \%$ yield. In all cases, a single diastereomer was observed by ${ }^{1} \mathrm{H}$ NMR. Phosphinoylation with $\mathrm{PH}_{2} \mathrm{P}(\mathrm{O}) \mathrm{Cl}$ was not successful in our hands. 


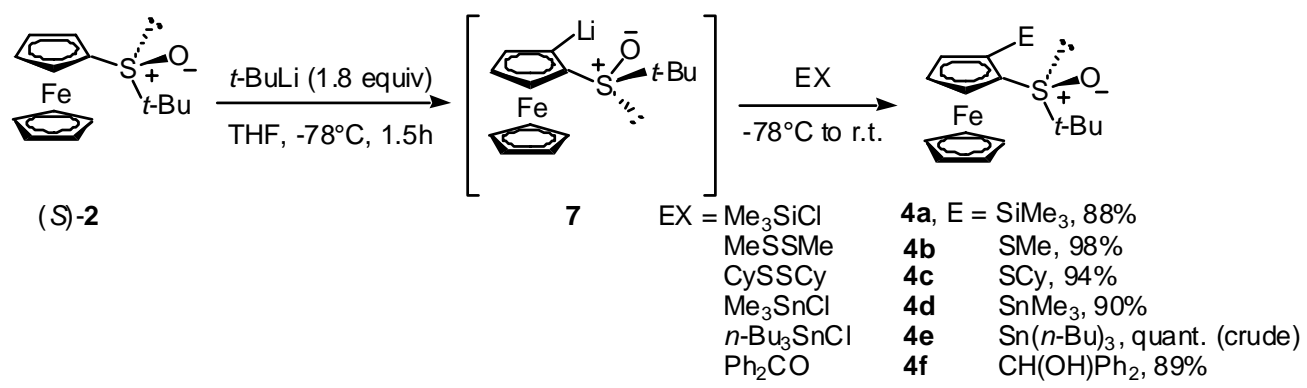

\section{Scheme 4}

We have also considered introducing alkyl or aryl groups in the ortho-position. An entry to an ortho-chain was to treat the sulfinylferrocene anion with a carbonyl compound, such as benzophenone (Scheme 4), affording hydroxyferrocene 4f. For the introduction of an aryl group, two precedent were reported, ${ }^{31,34}$ including a Negishi type coupling of a zinc metalated $p$-tolylsulfinylferrocene, but we were not able to extend this reaction to $t$-butylsulfinylferrocene 2. As an alternative, we have examined the Stille coupling of the tin derivative 4d with phenyl iodide. No coupling was observed with $\mathrm{Pd}\left(\mathrm{PPh}_{3}\right)_{4}$ in toluene or THF at reflux. Catalysis ${ }^{35}$ of $\mathrm{Pd}_{2} \mathrm{dba}_{3}$, in the presence of triphenylarsine and $\mathrm{CuI}$, provided phenyl ferrocene $\mathbf{4 g}$, albeit in modest yield (Scheme 5).

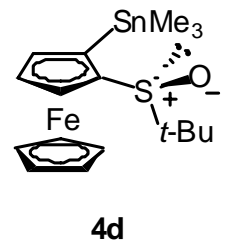

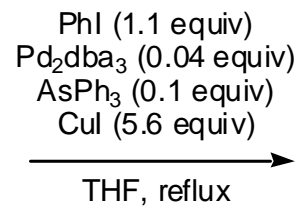

THF, reflux

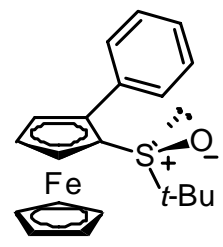

4g, $22 \%$

\section{Scheme 5}

Our third starting material was cyclohexylsulfinylferrocene 1, which has not yet been orthometallated. A further challenge here is the presence of another acidic proton, alpha to the sulfinyl group. Reaction of 1 with one equivalent of $n$-BuLi at $-78^{\circ} \mathrm{C}$ and addition of iodomethane led to the formation of $\alpha$-methyl sulfoxide 8 (53\%), demonstrating higher acidity on the sulfoxide alkyl chain (Scheme 6). Use of an excess (4.2 equiv) of $n$-BuLi in the presence of TMEDA and an excess of MeI (6 equiv) did not produce a bis-alkylated compound, with an ortho-methyl. Reaction with 2.2 equiv $n$-BuLi and quench with a single equivalent of TMSCl did not lead either to the selective formation of the desired ortho-silyl ferrocene. Further utilization of cyclohexylsulfinyl ferrocene 1 was stopped. 


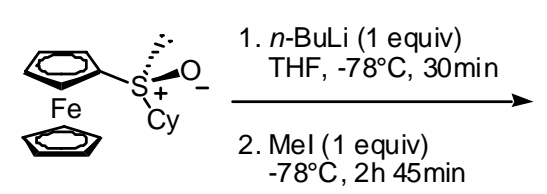

(S)-1

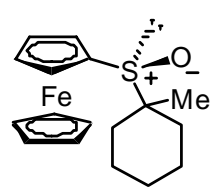

8, $53 \%$

\section{Scheme 6}

At this stage, only compounds $\mathbf{4 b}, \mathbf{4 c}, \mathbf{6 a}, \mathbf{6 b}$ were possessing the sulfanyl group requisite for epoxidation though sulfur ylides. It was necessary to reduce the sulfinyl moiety of other compounds: 4a, 4b, 4d, 4g, 4f. We have considered two reasonably mild reducing agents: trichlorosilane/triethylamine, or borane. Utilization of $\mathrm{HSiCl}_{3} / \mathrm{Et}_{3} \mathrm{~N}$ was effective with sulfoxides 4a, 4b, 4d, 4g (Scheme 7). The corresponding sulfides 5a, 5b, 5d, 5g were obtained in 53-90\% yields.
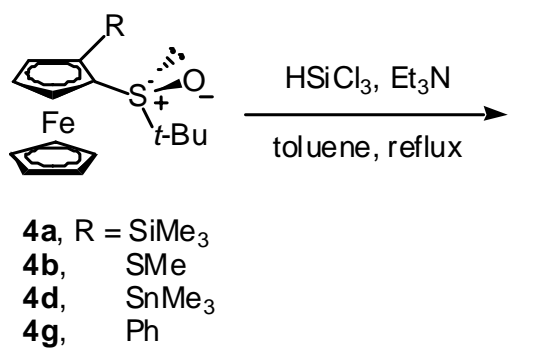

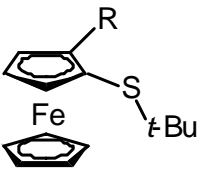

$5 a, 84 \%$

5b, $53 \%$

$5 d, 80 \%$

$5 \mathbf{5}, 91 \%$

\section{Scheme 7}

For sulfoxide $4 \mathrm{f}$ we desired to reduce also the benzylic hydroxyl group. A literature precedent, ${ }^{36}$ in the context of a drug process development, has shown that a sulfoxide moiety can assist the reduction of an alkene otherwise sluggish towards borane reaction. We were glad to observe that addition of borane-dimethyl sulfide to hydroxyl sulfinyl ferrocene 4 f provided compound 5f, with both desired reductions (Scheme 8).

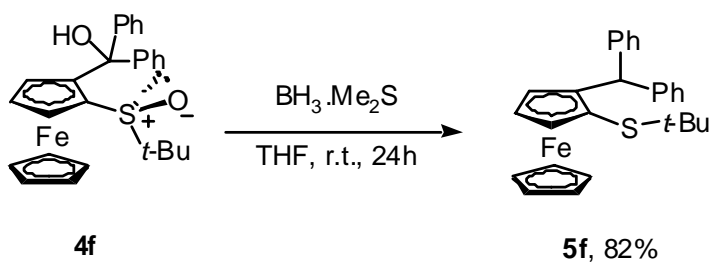

\section{Scheme 8}

We propose a mechanism (Figure 4), which involves prior complexation of the borane with the sulfinyl group, internal delivery of a hydride to the benzylic cationic center (with added stabilization due to the adjacent ferrocene), and subsequent reduction of the sulfoxide. 


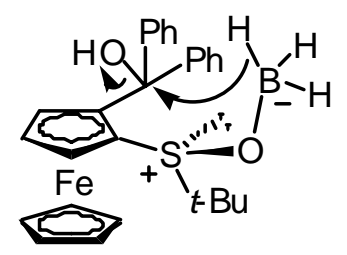

\section{Figure 4}

So, our synthetic study has led us to the preparation of 10 new planar chiral sulfides, available for the exploration of their behavior in asymmetric epoxidation.

\section{Evaluation of planar chiral sulfides as source of ylides for asymmetric epoxidation of aldehydes}

The choice of reaction conditions arose from our previous studies. ${ }^{15,19}$ We had devised a very simple procedure. All reagents are mixed at the start: chiral sulfide, benzyl bromide, sodium iodide, aldehyde, sodium hydroxide and a 9:1 tert-butanol/water mixture as solvent. The sulfide is used in a catalytic amount: 0.2 equivalent versus the aldehyde. Sodium iodide, or tetra$n$-butylammonium iodide, has been shown to accelerate the epoxidation, normally slower, probably by halide exchange to provide more reactive benzyl iodide. The nature of the solvent is critical: a polar medium is necessary to bring stabilization of the charged intermediates (sulfonium salt and betaine). tert-Butanol and water (roughly optimized at a 9:1 ratio) play a specific role in making the reaction chemo- and enantioselective. ${ }^{14,15}$ Thus, we have chosen the same conditions to explore the epoxidation of the various ferrocenyl sulfides, with benzaldehyde as a model (Scheme 9).

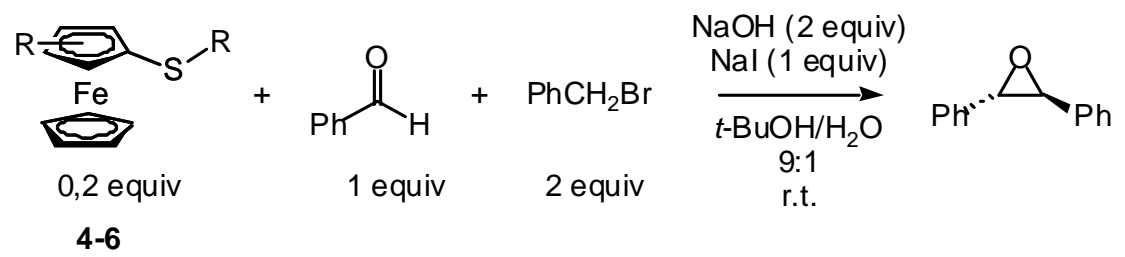

\section{Scheme 9}

With the exception of silyl compound 5a, all sulfides have led to the formation of stilbene oxide (Table 1). Unfortunately, the reactions are sluggish: the $t$-butylsulfanyl compounds required approximately 14 days at room temperature. Only the reactions with methylsulfides $5 \mathbf{b}$ and 6a were completed in 3 days (entries 2,7). 


\section{Table 1}

\begin{tabular}{|c|c|c|c|c|c|c|c|c|}
\hline & \multirow[t]{2}{*}{ Sulfide } & & Time & \multicolumn{4}{|c|}{ Stilbene oxide } & \multirow{2}{*}{$\begin{array}{c}\text { Sulfide } \\
\text { recovery } \\
\%\end{array}$} \\
\hline & & & (d) & $\begin{array}{r}\text { Yield } \\
(\%)\end{array}$ & trans/cis ${ }^{\mathrm{a}}$ & $\begin{array}{c}\text { e.e. } \\
(\%)\end{array}$ & Config. & \\
\hline 1 & & $5 a$ & 14 & 0 & - & - & - & 95 \\
\hline 2 & & $5 \mathbf{b}$ & 3 & 77 & $80 / 20$ & 6 & $(R, R)$ & 0 \\
\hline 3 & & $4 b$ & 8 & 84 & $89 / 11$ & 2 & $(S, S)$ & 65 \\
\hline 4 & $\stackrel{\mathrm{Fe}}{\mathrm{Fe}}$ & $4 c$ & 14 & 32 & $73 / 27$ & 50 & $(S, S)$ & 89 \\
\hline 5 & & $5 d$ & 14 & 32 & $73 / 27$ & 41 & $(R, R)$ & 0 \\
\hline 6 & & $5 f$ & 14 & 85 & $86 / 14$ & 0 & - & 60 \\
\hline 7 & & $6 a$ & 3.5 & 91 & $76 / 24$ & 40 & $(R, R)$ & 0 \\
\hline 8 & & $6 b$ & 14 & 36 & $83 / 17$ & 53 & $(R, R)$ & 0 \\
\hline
\end{tabular}

${ }^{a}$ Measured by GC or ${ }^{1} \mathrm{H}$ NMR spectroscopy of the crude product. ${ }^{\mathrm{b}}$ Determined by enantioselective HPLC on Daicel Chiralpak AD-H column.

The yields ranged from 32 to $91 \%$. The chiral sulfides could be recovered in 3 examples. The diastereoselectivities vary from 73:27 to $89: 11$.

A large diversity was observed for enantioselectivities, from a racemic oxirane (entry 6) to e.e'.s up to $53 \%$ (entry 8). Both absolute senses of induction were obtained. Although no high stereocontrol was performed, the various examples bring a number of information.

Compound $\mathbf{5 b}$ is a bis(sulfide) with steric differentiation of the two groups. A non-bonding interaction was also hoped between the sulfonium center and the t-butyl sulfur atom. The chemical yield is satisfactory $(77 \%$, entry 2$)$ but the asymmetric induction is almost absent $(6 \%$ 
e.e.). With a trimethylstannyl group (entry 5) a moderate yield and enantioselectivity (41\% e.e.) in favor of the $(R, R)$ oxirane are obtained.

Two sulfides bearing a sulfoxide group led to epoxidation. With the methyl sulfide $\mathbf{4 b}$, an excellent yield is observed for a racemic oxirane (entry 3)! Introduction of steric hindrance by replacement into a cyclohexyl group on the sulfur atom (entry 4) retarded the reaction but gave a $50 \%$ e.e. In both cases, the auxiliaries were recovered. We propose the accompanying model to explain the formation of the $(S, S)$ oxirane, through favored formation of a diastereomeric sulfonium salt, an anti ylide and a backward attack by the aldehyde (Scheme 8).

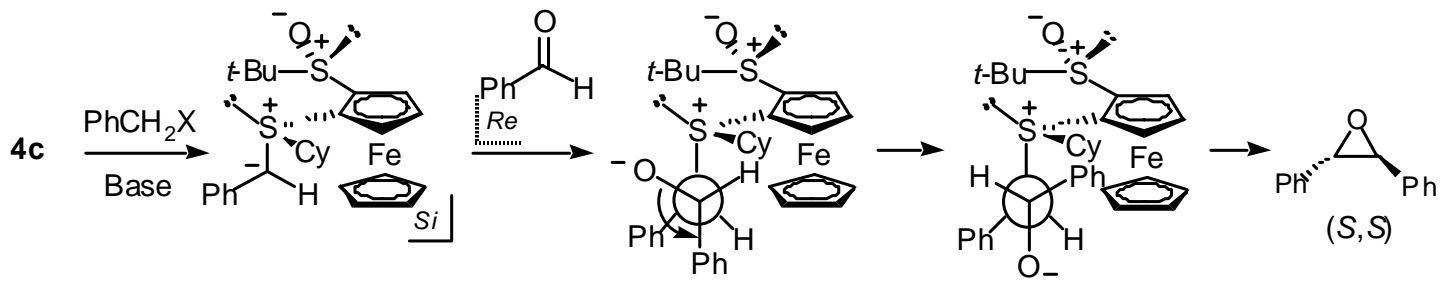

\section{Scheme 10}

A $41 \%$ e.e. was observed for sulfide $5 \mathbf{d}$ bearing an ortho-trimethylstannyl group.

Three sulfides incorporate a carbon chain in the ortho-position. The diphenylmethyl sulfide 5f gave a good yield (85\%) and diastereoselectivity (86:14) but a very disappointing HPLC analysis with a racemic product (entry 6). The ortho-phenyl sulfide $5 g$ (Figure 2) led to significant excesses, which however were not reproducible. With sulfides $\mathbf{6 a}$ and $\mathbf{6 b}$, we were expecting a stabilizing interaction of the sulfonium moiety with the nucleophilic amine, involving a hypervalent sulfurane intermediate, with trigonal bipyramidal geometry and conformational rigidity. ${ }^{37,38}$ For methylsulfide 6a (entry 7), the reaction is relatively rapid (3.5 days) and a $40 \%$ enantiomeric excess is observed. Replacement of the methyl by a cyclohexyl group (6b, entry 8) increased the selectivity (53\% e.e., and 83:17 trans/cis ratio), but lowered rate and yield.

\section{Discussion}

A variety of planar chiral sulfoxides and sulfides have been synthesized for the first time. Standard routes have been explored. The ortho-lithiation of $t$-butylsulfinylferrocene and reaction with electrophiles is very efficient (88-100\%). Most of the sulfides bear two functional groups and may be used as bidentate ligands for various purposes of asymmetric synthesis, especially as alternative to phosphines with semi-labile metal interactions..$^{39-41}$

The reaction rates of epoxidation were not improved, as compared to previous results with aliphatic sulfides. The $t$-butyl group was introduced in order to secure differentiation of the sulfur lone pairs. Its steric hindrance is not solely responsible for moderate rates, as shown by the 
results with a ring fused sulfide $\mathbf{B}$, with much less hindrance around the sulfur atom and epoxidation reactions which are still slow. In 3 cases, the sulfides could be recovered (entries $3,4,6)$.

Diastereoselectivities $^{12}$ range from $73: 27$ to $86: 14$. They arise from two competing parameters. ${ }^{18}$ The steric hindrance favors trans oxirane formation. The aromatic nature of the ferrocenyl substituent favors kinetic control leading to trans and cis mixtures. This stands in contrast to dialiphatic sulfides for which Aggarwal and co-workers have shown ${ }^{42}$ that the formation of the syn betaine, leading to cis oxiranes is reversible. The anti betaines were formed irreversibly and the trans oxiranes were predominantly obtained.

For the absolute stereoselectivity, no major breakthrough has been accomplished here, but we have shown that planar chirality has led to e.e.'s around 50\%. The two cases incorporated a complementary central chirality (stereogenic carbon or sulfur atoms). We have not tested the diastereomers (matched or unmatched configurations). The example reported previously with an ortho-tosylamino group exhibited only planar chirality and led to a $67 \%$ e.e.

Further work, with different structure types, is definitely necessary to increase the rate of the sulfur ylide epoxidation reaction, as well as the scope of the carbonyl compounds and halide substrates.

\section{Conclusions}

Nine new planar chiral ferrocenyl sulfides have been prepared in a straightforward manner, often in 3 steps. The evaluation as catalysts for asymmetric epoxidation of benzaldehyde has brought interesting observations. Chemical yields are moderate to excellent. Planar chirality leads to asymmetric induction, with moderate e.e.'s.

\section{Experimental Section}

General Procedures. All non-aqueous reactions were carried out in oven-dried, septum-capped flasks, and under an atmospheric pressure of $\mathrm{N}_{2}$. All liquid reagents were transferred via ovendried syringes. THF was distilled from sodium-benzophenone, $\mathrm{Et}_{2} \mathrm{O}$ from $\mathrm{LiAlH}_{4}$, toluene from $\mathrm{Na}$, or purified on Puresolv ${ }^{\mathrm{TM}}$ apparatus developed by Innovative Technology Inc. $n$-Hexane and $\mathrm{CH}_{2} \mathrm{Cl}_{2}$ were distilled from $\mathrm{P}_{2} \mathrm{O}_{5}$ and $\mathrm{CaH}_{2}$ respectively. $\mathrm{Et}_{3} \mathrm{~N}$ was refluxed with $\mathrm{KOH}$ pellets and distilled. All reagents were commercially available and used without further purification unless otherwise noted. Lithium bases were purchased from Aldrich and concentrations were checked before experiments by titration with diphenylacetic acid.

Thin layer chromatography (TLC) was performed on Alugram SIL G/UV 254 plates and the plates were visualized with UV light and vanillin $\left(600 \mathrm{mg}\right.$ in $100 \mathrm{~mL} \mathrm{EtOH}$ and $\left.2 \mathrm{~mL} \mathrm{H}_{2} \mathrm{SO}_{4}\right)$ or phosphomolybdic acid (1 g in $100 \mathrm{~mL} i$-PrOH). Chromatographic purification of compounds 
was achieved with Merck 60 silica gel (40-63 $\mu \mathrm{m})$ or with Flashmaster Personal apparatus (AIT) and Flashsmart pack silica (BP SUP quality). Petroleum ether refers to the fraction with bp 35$60{ }^{\circ} \mathrm{C}$. High pressure liquid chromatography (HPLC) was performed on a Waters apparatus with a diode array M996 detector and a Daicel ChiralPak AD column $250 \times 4.6 \mathrm{~mm}(\mathrm{~L} \times$ I.D.) $5 \mu \mathrm{m}$ : AS-H, or OD-H, or AD, or AD-H. $t$-Butylbenzene was used as $\mathrm{t}_{0}$. GC analyses were carried out on a Varian CP-3800 apparatus with a FID and a JW DB5 capillary column $(30 \mathrm{~m} \times 0.32 \mathrm{~mm}$, L $\times$ I.D.). Melting points were obtained on an Electrothermal IA9000 capillary apparatus and are uncorrected.

Known compound structures were assigned by comparison with the literature spectroscopic data. ${ }^{1} \mathrm{H}$ NMR and ${ }^{13} \mathrm{C}$ NMR spectra were recorded on a Bruker DPX 250 or on a Bruker DRX 400. Data appear in the following order: chemical shift in ppm, multiplicity (s, singlet; $d$, doublet; t, triplet; q, quadruplet; m, multiplet), number of protons, coupling constant $J$ and assignment. TMS is the internal standard for the $\mathrm{CDCl}_{3}$ solutions. IR spectra were recorded on a Perkin-Elmer 16 PC FT-IR spectrophotometer. Wave numbers $v$ were reported in $\mathrm{cm}^{-1}$. GC/MS analyses were recorded on a Varian 3800 (GC) and Saturn 2000 (MS) instruments. CP-SIL 8CB (Low-Bleed/MS) column (dimensions $30 \mathrm{~m} \times 0.25 \mathrm{~mm}$ ), with $5 \%$ phenyl/95\% dimethylpolysiloxane as the stationary phase, was used for the analysis. Microanalyses were obtained using a ThermoQuest instrument. HRMS were recorded on a Jeol GCmate or by LCMS, on a Xterra MS column.

(S)-Cyclohexylsulfinylferrocene (1). A suspension of ferrocene (245 mg, $1.32 \mathrm{mmol}) \mathrm{in} \mathrm{THF} / \mathrm{n}$ hexane $(\mathrm{v} / \mathrm{v} 1 / 1,5.00 \mathrm{~mL})$ was stirred at room temperature for $30 \mathrm{~min}$ and then cooled to $0{ }^{\circ} \mathrm{C}$. $t$-BuLi $(750 \mu \mathrm{L}, 1.12 \mathrm{mmol}, 1.50 \mathrm{M}$ in pentane) was then added at a rate of approximately $1 \mathrm{mmol} \cdot \mathrm{min}^{-1}$. After $30 \mathrm{~min}$, the mixture was cooled to $-78^{\circ} \mathrm{C}$ and $(S)$-DAG cyclohexylsulfinate (447 mg, $1.14 \mathrm{mmol}$, ee 95\%) was added. After $1.5 \mathrm{~h}$, the mixture was allowed to warm to room temperature. Hydrolysis was performed with saturated aqueous $\mathrm{NaCl}(5 \mathrm{~mL})$ and the aqueous layer was extracted with dichloromethane $(3 \times 5 \mathrm{~mL})$. The organic layer was dried over $\mathrm{MgSO}_{4}$ and concentrated. Column chromatography using petroleum ether/ethyl acetate (v/v 9/1 to 3/7) afforded $137 \mathrm{mg}(0.43 \mathrm{mmol}, 39 \%)$ of ferrocenyl sulfoxide $(S)-1$ as an orange solid. ${ }^{1} \mathrm{H}$ NMR $\left(\mathrm{CDCl}_{3}\right)$ : 4.69 (m, 1H, Cp ring), 4.41-4.35 (m, 8H, Cp ring), 2.56 (m, 1H, Cy), 2.08-1.19 (m, 10H, Cy). ${ }^{13} \mathrm{C} \mathrm{NMR}\left(\mathrm{CDCl}_{3}\right): 69.9,69.7,69.6,68.8,64.4,63.3,25.7,25.6,25.4,25.2$. IR: 3072, 2920, 2850, 1459, 1035. HRMS Calcd for $\mathrm{C}_{16} \mathrm{H}_{20} \mathrm{FeOS}$ : 316.0584. Found: 316.0592. HPLC: Daicel Chiralpak AD column $250 \times 4.6$ (L $\times$ I.D. $), n$-hexane $/ i-P r O H ~(v / v: ~ 90 / 10)$ at $1 \mathrm{~mL} \cdot \mathrm{min}^{-1}$, $204 \mathrm{~nm}, \mathrm{rt} .8 .18 \mathrm{~min}(S), 9.96 \mathrm{~min}(R)$.

(S)-t-Butylsulfinylferrocene(2). [149094-96-2].25,43 To a solution of ferrocene (596 mg, $3.20 \mathrm{mmol})$ in THF $(25 \mathrm{~mL})$ was added $t$-BuOK $(385 \mu \mathrm{L}, 1 \mathrm{M}$ in THF, $0.38 \mathrm{mmol})$. The mixture was cooled to $-78^{\circ} \mathrm{C}$ and $t$-BuLi (4.30 mL, $6.41 \mathrm{mmol}, 1.49 \mathrm{M}$ in hexanes) was added dropwise. The reaction mixture was kept at $-78^{\circ} \mathrm{C}$ for $1.5 \mathrm{~h}$ and $1 \mathrm{~h}$ at room temperature. The red solution was then cannulated dropwise into a cold solution $\left(-55^{\circ} \mathrm{C}\right)$ of $\left(S_{S}\right)-(-)$-t-butyl-tbutanethiosulfinate $(633 \mathrm{mg}, 3.26 \mathrm{mmol})$ in THF $(15 \mathrm{~mL})$. After $1 \mathrm{~h}$ at $-55^{\circ} \mathrm{C}$, water $(20 \mathrm{~mL})$ 
was added. The aqueous layer was extracted with $\mathrm{Et}_{2} \mathrm{O}(2 \times 20 \mathrm{~mL})$, the combined organic layers were dried over $\mathrm{MgSO}_{4}$ and evaporated to dryness. Column chromatography using $n$ heptane/ethyl acetate (v/v 7:3) gave $2(634 \mathrm{mg}, 2.18 \mathrm{mmol}, 68 \%)$ as a cotton-like yellow solid. ${ }^{1} \mathrm{H}$ NMR $\left(\mathrm{CDCl}_{3}\right): 4.69$ (m, 1H, Cp-H), 4.42-4.35 (m, 8H, Cp-H), 1.12 (s, 9H, t-Bu). ${ }^{13} \mathrm{C}$ NMR $\left(\mathrm{CDCl}_{3}\right): 86.4,70.0,69.9,69.6,69.3,65.3,54.9,22.7$. HPLC: Daicel Chiralpak AS-H column $250 \times 4.6\left(\mathrm{~L} \times\right.$ I.D.) $5 \mu \mathrm{m}, n$-hexane/i-PrOH (v/v: 98/2) at $1 \mathrm{~mL} \cdot \mathrm{min}^{-1}, 203 \mathrm{~nm}, 18^{\circ} \mathrm{C} .5 .64 \mathrm{~min}$ $(S), 7.21 \min (R)$

ortho-Substitution of $\boldsymbol{t}$-butylsulfinylferrocene(2). ${ }^{25,43}$ To a cold solution $\left(-78^{\circ} \mathrm{C}\right)$ of $t$-butylsulfinylferrocene $2(0.16 \mathrm{mmol})$ in dry THF $(2 \mathrm{~mL})$ was added $t$-BuLi $(0.23 \mathrm{mmol})$. The mixture was stirred for $1.5 \mathrm{~h}$ at $-78^{\circ} \mathrm{C}$ and electrophile $(0.25 \mathrm{mmol})$ was added. The reaction mixture was stirred $0.5 \mathrm{~h}$ at $-78^{\circ} \mathrm{C}$, then allowed to warm to room temperature. The reaction was monitored by TLC using $n$-heptane/ethyl acetate (v/v 7:3). Hydrolysis was performed with water $(2 \mathrm{~mL})$. The aqueous layer was extracted with $\mathrm{Et}_{2} \mathrm{O}(2 \times 3 \mathrm{~mL})$. The combined organic layers were dried over $\mathrm{MgSO}_{4}$ and then evaporated to dryness. The crude product was purified by column chromatography.

$\left(S_{\mathrm{Fc}}, S_{\mathrm{S}}\right)$-1-t-Butylsulfinyl-2-trimethylsilylferrocene (4a). The general procedure was followed using $t$-butylsulfinylferrocene $(S)-2(47 \mathrm{mg}, 0.16 \mathrm{mmol})$, THF $(2 \mathrm{~mL}), t$-BuLi $(155 \mu \mathrm{L}$, $0.23 \mathrm{mmol}, 1.49 \mathrm{M}$ in hexanes) and $\mathrm{TMSCl}(31 \mu \mathrm{L}, 0.24 \mathrm{mmol})$. Column chromatography using dichloromethane/ethyl acetate (v/v 7:3) afforded 4a (54 mg, $0.14 \mathrm{mmol}, 88 \%)$ as an orange solid. mp: 80-81 ${ }^{\circ} \mathrm{C} .{ }^{1} \mathrm{H}$ NMR $\left(\mathrm{CDCl}_{3}\right): 4.51$ (m, 2H, Cp-H), 4.31 (m, 6H, Cp-H), 1.14 (s, 9H, t-Bu), 0.37 (s, 9H, $\left.\mathrm{SiMe}_{3}\right) .{ }^{13} \mathrm{C} \mathrm{NMR}\left(\mathrm{CDCl}_{3}\right): 91.3,76.7,71.9,71.1,70.7,70.0,55.8,23.3$, 1.80. IR: 3060, 2952, 1654, 1240, 1172, 1044. HRMS Calcd for $\left[\mathrm{C}_{17} \mathrm{H}_{26} \mathrm{FeOSSi}-\mathrm{H}\right]^{+}: 363.0901$. Found: 363.0936. Anal. Calcd for $\mathrm{C}_{17} \mathrm{H}_{26}$ FeOSSi: C, 56.34; H, 7.23; S, 8.85. Found: C, 56.36; H, 7.54; $\mathrm{S}, 8.23$.

$\left(S_{\mathrm{Fc}}, S_{\mathrm{S}}\right)$-1-t-Butylsulfinyl-2-methylsulfanylferrocene(4b). The general procedure was followed using t-butylsulfinylferrocene $(S)-2(47 \mathrm{mg}, 0.16 \mathrm{mmol})$, THF $(2 \mathrm{~mL}), t$-BuLi $(165 \mu \mathrm{L}$, $0.23 \mathrm{mmol}, 1.49 \mathrm{M}$ in hexanes) and dimethyl disulfide $(22 \mu \mathrm{L}, 0.25 \mathrm{mmol})$. Column chromatography using $n$-heptane/ethyl acetate (v/v 7:3) afforded $\mathbf{4 b}(56 \mathrm{mg}, 0.16 \mathrm{mmol}, 98 \%)$ as an orange solid. mp: $134-136{ }^{\circ} \mathrm{C} .{ }^{1} \mathrm{H}$ NMR $\left(\mathrm{CDCl}_{3}\right): 4.45(\mathrm{~m}, 1 \mathrm{H}, \mathrm{Cp}-\mathrm{H}), 4.41$ (s, 5H, Cp-H), $4.36(\mathrm{~m}, 1 \mathrm{H}, \mathrm{Cp}-\mathrm{H}), 4.33(\mathrm{~m}, 1 \mathrm{H}, \mathrm{Cp}-\mathrm{H}), 2.40(\mathrm{~s}, 3 \mathrm{H}, \mathrm{S}-\mathrm{Me}), 1.24(\mathrm{~s}, 9 \mathrm{H}, t-\mathrm{Bu}) .{ }^{13} \mathrm{C}$ NMR( $\left(\mathrm{CDCl}_{3}\right):$ 87.5, 83.5, 71.6, 70.4, 69.3, 68.6, 56.9, 23.7, 17.7.IR: 3068, 2960, 2916, 1654, 1362, 1180, 1038. HRMS Calcd for $\left[\mathrm{C}_{15} \mathrm{H}_{20} \mathrm{FeOS}_{2}-\mathrm{H}\right]^{+}:$337.0383. Found: 337.0403.

$\left(S_{\mathrm{Fc}}, S_{\mathrm{S}}\right)$-1-t-Butylsulfinyl-2-cyclohexylsulfanylferrocene(4c). The general procedure was followed using $t$-butylsulfinylferrocene $(S)-2(48 \mathrm{mg}, 0.16 \mathrm{mmol})$, THF $(2 \mathrm{~mL}), t$-BuLi $(170 \mu \mathrm{L}$, $0.25 \mathrm{mmol}, 1.49 \mathrm{M}$ in hexanes) and dicyclohexyl disulfide (54 $\mu \mathrm{L}, 0.25 \mathrm{mmol})$. Column chromatography using dichloromethane/ethyl acetate (v/v 7:3) afforded 4c (63 mg, 0.16 mmol, 94\%) as an orange solid. mp: $152-154{ }^{\circ} \mathrm{C} .{ }^{1} \mathrm{H} \mathrm{NMR}\left(\mathrm{CDCl}_{3}\right): 4.56(\mathrm{~m}, 1 \mathrm{H}, \mathrm{Cp}-\mathrm{H}), 4.39-4.35(\mathrm{~m}$, $7 \mathrm{H}, \mathrm{Cp}-\mathrm{H}), 2.94(\mathrm{~m}, 1 \mathrm{H}, \mathrm{Cy}), 2.11-1.21(\mathrm{~m}, 10 \mathrm{H}, \mathrm{Cy}), 1.29(\mathrm{~s}, 9 \mathrm{H}, t-\mathrm{Bu}) .{ }^{13} \mathrm{C} \mathrm{NMR}\left(\mathrm{CDCl}_{3}\right)$ : 84.2, 83.9, 73.1, 72.0, 70.1, 69.2, 56.5, 47.1, 33.9, 33.7, 26.2, 25.8, 24.0. IR: 3072, 2924, 2848, 1654, 1458, 1178, 1040. HRMS Calcd for $\left[\mathrm{C}_{20} \mathrm{H}_{28} \mathrm{FeOS}_{2}-\mathrm{H}\right]^{+}: 405.1009$. Found: 405.1007. 
$\left(R_{\mathrm{Fc}}, S_{\mathrm{S}}\right)$-1-Trimethylstannyl-2-t-butylsulfinylferrocene(4d). The general procedure was followed using $t$-butylsulfinylferrocene $(S)-2(206 \mathrm{mg}, 0.71 \mathrm{mmol})$, THF $(7 \mathrm{~mL}), t$-BuLi $\left(735 \mu \mathrm{L}, 1.07 \mathrm{mmol}, 1.45 \mathrm{M}\right.$ in hexanes) and $\mathrm{Me}_{3} \mathrm{SnCl}(212 \mathrm{mg}, 1.06 \mathrm{mmol})$ in $\mathrm{THF}(1 \mathrm{~mL})$. Column chromatography using $n$-heptane/ethyl acetate (v/v 100:0 to 90:10) afforded 4d (291 mg, $0.64 \mathrm{mmol}, 90 \%)$ as an orange oily solid. ${ }^{1} \mathrm{H} \mathrm{NMR}\left(\mathrm{CDCl}_{3}\right): 4.54(\mathrm{~m}, 1 \mathrm{H}, \mathrm{Cp}-\mathrm{H}), 4.50$ (m, 1H, Cp-H), 4.29 (s, 5H, Cp-H), 4.27 (m, 1H, Cp-H), 1.09 (s, 9H, t-Bu), 0.32 (s, 9H, SnMe $).$ ${ }^{13} \mathrm{C} \mathrm{NMR}\left(\mathrm{CDCl}_{3}\right):$ 90.5, 75.6, 73.2, 69.8, 69.4, 66.8, 55.5, 23.0, -5.6.IR: 2923, 2853, 1637, 1458, 1178, 1084, 1035. HRMS Calcd for $\left[\mathrm{C}_{17} \mathrm{H}_{26} \mathrm{FeOSSn}-\mathrm{H}\right]^{+}: 455.0154$. Found: 455.0147.

$\left(R_{\mathrm{Fc}}, S_{\mathrm{S}}\right)$-1-Tri(n-butyl)stannyl-2-t-butylsulfinylferrocene(4e). The general procedure was followed using $t$-butylsulfinylferrocene $(S)-2(200 \mathrm{mg}, 0.69 \mathrm{mmol})$, THF $(7 \mathrm{~mL}), t$-BuLi $\left(715 \mu \mathrm{L}, 1.04 \mathrm{mmol}, 1.45 \mathrm{M}\right.$ in hexanes) and $\mathrm{Bu}_{3} \mathrm{SnCl}(310 \mu \mathrm{L}, 1.03 \mathrm{mmol}, 90 \%)$. The product was obtained in quantitative yield and used as a crude material. Column chromatography using $n$-heptane/ethyl acetate (v/v 1:0 to 0:1) led to decomposition. ${ }^{1} \mathrm{H}$ NMR $\left(\mathrm{CDCl}_{3}\right): 4.52(\mathrm{~m}, 1 \mathrm{H}$, Cp-H), 4.48 (m, 1H, Cp-H), 4.37 (s, 5H, Cp-H), 4.25 (m, 1H, Cp-H), 1.57-0.90 (m, 36H, t-Bu and $n-\mathrm{Bu})$.

$\left(S_{\mathrm{Fc}}, S_{\mathrm{S}}\right)$-1-t-Butylsulfinyl-2-diphenylhydroxymethylferrocene(4f). The general procedure was followed using $t$-butylsulfinylferrocene $(S)-2(50 \mathrm{mg}, 0.17 \mathrm{mmol})$, THF $(2 \mathrm{~mL}), t$-BuLi $(160 \mu \mathrm{L}$, $0.26 \mathrm{mmol}, 1.65 \mathrm{M}$ in hexanes) and acetophenone $(47 \mu \mathrm{L}, 0.26 \mathrm{mmol})$ in THF $(1 \mathrm{~mL})$. Column chromatography using $n$-heptane /ethyl acetate (v/v 100:0 to 90:10) afforded 4 f (72 $\mathrm{mg}$, $0.15 \mathrm{mmol}, 89 \%)$ as an orange solid. $\mathrm{mp}: 183-184^{\circ} \mathrm{C} .{ }^{1} \mathrm{H}$ NMR $\left(\mathrm{CDCl}_{3}\right): 7.65(\mathrm{~m}, 2 \mathrm{H}, \mathrm{Ph}), 7.56$ $(\mathrm{m}, 1 \mathrm{H}, \mathrm{Ph}), 7.34-7.16(\mathrm{~m}, 7 \mathrm{H}, \mathrm{Ph}), 4.47$ (m, 1H, Cp-H), $4.40(\mathrm{~m}, 1 \mathrm{H}, \mathrm{Cp}-\mathrm{H}), 4.37$ (s, 5H, $\mathrm{Cp}-\mathrm{H}), 3.98$ (m, 1H, Cp-H), 0.79 (s, 9H, t-Bu). ${ }^{13} \mathrm{C} \mathrm{NMR}\left(\mathrm{CDCl}_{3}\right): 149.9,146.4,128.1,127.5$, $127.4,127.1,126.6,100.4,80.2,77.2,76.7,74.6,71.8,71.6,69.5,57.2,23.4$. IR: 3428 (O-H), $3101,3063,2962,1655,1466,1169,1052$, 1003. HRMS Calcd for $\left[\mathrm{C}_{27} \mathrm{H}_{28} \mathrm{FeO}_{2} \mathrm{~S}-\mathrm{H}\right]^{+}$: 473.1238. Found: 473.1259.

$\left(\boldsymbol{S}_{\mathrm{Fc}}, \boldsymbol{S}_{\mathrm{S}}\right)$-1-t-Butylsulfinyl-2-phenylferrocene (4g). A degassed solution of $\mathrm{AsPh}_{3}(0.01 \mathrm{mmol}$, $4 \mathrm{~g}), \mathrm{CuI}(0.62 \mathrm{mmol}, 118 \mathrm{mg})$ and $\mathrm{Pd}_{2} \mathrm{dba}_{3}(0.004 \mathrm{mmol}, 4 \mathrm{mg})$ in THF $(3 \mathrm{~mL})$ was stirred at room temperature for $30 \mathrm{~min}$. $\mathrm{PhI}(0.12 \mathrm{mmol}, 14 \mu \mathrm{L})$ was then added and the resulting solution was degassed and stirred for another $30 \mathrm{~min}$. Tri- $n$-butylstannyl-t-Butylsulfinylferrocene 4d $(0.11 \mathrm{mmol}, 50 \mathrm{mg})$ in THF $(2 \mathrm{~mL})$ was then added via cannula. After $1 \mathrm{~h}$ at room temperature, the mixture was heated for $12 \mathrm{~h}$ and then filtrated through Celite. The crude product was purified by column chromatography using $n$-heptane/ethyl acetate (v/v: 9/1), affording compound $\mathbf{4 g}$ (50 mg, 22\%). ${ }^{1} \mathrm{H}$ NMR ( $\left.\mathrm{CDCl}_{3}\right): 7.91$ (m, 2H, Ph), 7.29-7.24 (m, 3H, Ph), 4.67 (m, 1H, Cp-H), 4.49 (m, 1H, Cp-H), 4.47 (m, 1H, Cp-H), 4.38 (s, 5H, Cp-H), 0.96 (s, 9H, t-Bu). ${ }^{13} \mathrm{C}$ NMR $\left(\mathrm{CDCl}_{3}\right): 137.5,131.1,127.6,126.8,88.9,85.7,73.5,71.4$ (2C), 69.1, 56.6, 24.0. IR: 2925, 2855, 1635, 1460, 1400, 1184, 967. HRMS Calcd for $\left[\mathrm{C}_{20} \mathrm{H}_{22} \mathrm{FeOS}-\mathrm{H}\right]^{+}: 367.0819$. Found: 367.0537.

Reduction of $\boldsymbol{t}$-butylsulfinylferrocenes 4 with $\mathbf{H S i C l}_{3} / \mathbf{E t}_{3} \mathbf{N}$. General procedure. ${ }^{39}$ To a solution of the sulfinylferrocene $(0.05 \mathrm{mmol})$ in dry toluene $(1 \mathrm{~mL})$ was added $\mathrm{Et}_{3} \mathrm{~N}(0.54 \mathrm{mmol})$ and $\mathrm{HSiCl}_{3}(0.79 \mathrm{mmol})$. The mixture was refluxed for $15 \mathrm{~h}$ and treated with aqueous $\mathrm{NaOH}$ $(2 \mathrm{~mL}, 10 \%)$. The aqueous layer was extracted with $\mathrm{CH}_{2} \mathrm{Cl}_{2}(2 \times 2 \mathrm{~mL})$. The combined organic 
layers were dried over $\mathrm{MgSO}_{4}$ and then evaporated to dryness. The crude product was purified by column chromatography.

(S)-1-t-Butylsulfanyl-2-trimethylsilylferrocene (5a). The general procedure was followed using compound 4a $(20 \mathrm{mg}, 0.05 \mathrm{mmol})$, toluene $(1 \mathrm{~mL}), \mathrm{Et}_{3} \mathrm{~N}(75 \mu \mathrm{L}, 0.54 \mathrm{mmol})$ and $\mathrm{HSiCl}_{3}$ $(80 \mu \mathrm{L}, 0.79 \mathrm{mmol})$. Column chromatography using 100\% $n$-heptane afforded $5 \mathbf{a}$ (16 $\mathrm{mg}$, $0.04 \mathrm{~mol}, 84 \%)$ as an orange oil. ${ }^{1} \mathrm{H} \mathrm{NMR}\left(\mathrm{CDCl}_{3}\right): 4.55(\mathrm{~m}, 1 \mathrm{H}, \mathrm{Cp}-\mathrm{H}), 4.41(\mathrm{~m}, 1 \mathrm{H}, \mathrm{Cp}-\mathrm{H})$, $4.17(\mathrm{~s}, 5 \mathrm{H}, \mathrm{Cp}-\mathrm{H}), 4.14(\mathrm{~m}, 1 \mathrm{H}, \mathrm{Cp}-\mathrm{H}), 1.22(\mathrm{~s}, 9 \mathrm{H}, t-\mathrm{Bu}), 0.34$ (s, 9H, $\left.\mathrm{SiMe}_{3}\right) .{ }^{13} \mathrm{C}$ $\operatorname{NMR}\left(\mathrm{CDCl}_{3}\right)$ : 82.1, 80.2, 75.6, 71.9, 69.7, 45.2, 31.2, 1.1.IR: 2955, 2899, 1406, 1361, 1246, 1177, 1036. HRMS Calcd for $\mathrm{C}_{17} \mathrm{H}_{26} \mathrm{FeSSi}$ : 346.0874. Found: 346.0539 .

(S)-1-t-Butylsulfanyl-2-methylsulfanylferrocene (5b). The general procedure was followed using compound $\mathbf{4 b}(20 \mathrm{mg}, 0.06 \mathrm{mmol})$, toluene $(1 \mathrm{~mL}), \mathrm{Et}_{3} \mathrm{~N}(80 \mu \mathrm{L}, 0.58 \mathrm{mmol})$ and $\mathrm{HSiCl}_{3}$ $(86 \mu \mathrm{L}, 0.85 \mathrm{mmol})$. Column chromatography using $n$-heptane/ethyl acetate (v/v 100:0 to 9:1) afforded $5 \mathbf{b}(10 \mathrm{mg}, 0.03 \mathrm{mmol}, 53 \%)$ as an orange oil. ${ }^{1} \mathrm{H} \mathrm{NMR}\left(\mathrm{CDCl}_{3}\right): 4.45(\mathrm{~m}, 1 \mathrm{H}, \mathrm{Cp}-\mathrm{H})$, 4.40 (m, 1H, Cp-H), 4.28 (m, 1H, Cp-H), 4.19 (s, 5H, Cp-H), 2.37 (s, 3H, CH ), 1.25 (s, 9H, t$\mathrm{Bu}) .{ }^{13} \mathrm{C} \mathrm{NMR}\left(\mathrm{CDCl}_{3}\right)$ : 77.9, 77.2, 76.7, 70.9, 69.8, 68.5, 46.3, 31.0, 18.6.IR: 2959, 2918, 1659, 1362, 1168, 1029. HRMS Calcd for $\mathrm{C}_{15} \mathrm{H}_{20} \mathrm{FeS}_{2}$ : 320.0356. Found: 320.0401 .

(R)-1-Trimethylstannyl-2-t-butylsulfanylferrocene (5d). The general procedure was followed using compound $4 \mathbf{d}(49 \mathrm{mg}, 0.11 \mathrm{mmol})$, toluene $(1.5 \mathrm{~mL}), \mathrm{Et}_{3} \mathrm{~N}(150 \mu \mathrm{L}, 1.08 \mathrm{mmol})$ and $\mathrm{HSiCl}_{3}(165 \mu \mathrm{L}, 1.63 \mathrm{mmol})$. Column chromatography using $n$-heptane/ethyl acetate (v/v 100:0 then $35: 1)$ afforded $5 \mathbf{d}(38 \mathrm{mg}, 0.09 \mathrm{mmol}, 80 \%)$ as an orange oil. ${ }^{1} \mathrm{H}$ NMR $\left(\mathrm{CDCl}_{3}\right): 4.52(\mathrm{~m}$, 1H, Cp-H), 4.42 (m, 1H, Cp-H), 4.13 (s, 5H, Cp-H), 4.10 (m, 1H, Cp-H), 1.19 (s, 9H, t-Bu), 0.34 (s, 9H, $\left.\mathrm{SnMe}_{3}\right) .{ }^{13} \mathrm{C} \mathrm{NMR}\left(\mathrm{CDCl}_{3}\right)$ : 79.2, 77.2, 76.2, 72.5, 69.4, 44.9, 31.0, -7.1. IR: 2956, 2922, 2853, 1637, 1449, 1408, 1082. HRMS Calcd for $\mathrm{C}_{17} \mathrm{H}_{26} \mathrm{FeSSn}$ : 438.0129. Found: 438.1013.

(S)-1-t-Butylsulfanyl-2-diphenylmethylferrocene (5f). To a solution of ferrocene $\mathbf{4 f}$ (5 $\mathrm{mg}$, $0.01 \mathrm{mmol})$ in dry THF $(0.5 \mathrm{~mL})$ was added $\mathrm{BH}_{3} \cdot \mathrm{Me}_{2} \mathrm{~S}(200 \mu \mathrm{L}, 0.20 \mathrm{mmol})$. The mixture was stirred at room temperature for $24 \mathrm{~h}$ and treated with water $(0.5 \mathrm{~mL})$. The aqueous layer was extracted with $\mathrm{CH}_{2} \mathrm{Cl}_{2}(2 \times 2 \mathrm{~mL})$. The combined organic layers were dried over $\mathrm{MgSO}_{4}$ and then evaporated to dryness. Column chromatography on neutral alumina using $n$-heptane/ethyl acetate (v/v 9:1) afforded $5 f(4 \mathrm{mg}, 0.01 \mathrm{mmol}, 82 \%)$ as an orange oil. ${ }^{1} \mathrm{H} \mathrm{NMR}\left(\mathrm{CDCl}_{3}\right): 7.60$ (m, 2H, Ph), 7.53 (m, 1H, Ph), 7.33-7.15 (m, 7H, Ph), 6.04 (s, 1H, CH), 4.51 (m, 1H, Cp-H), $4.27(\mathrm{~m}, 1 \mathrm{H}, \mathrm{Cp}-\mathrm{H}), 4.14(\mathrm{~s}, 5 \mathrm{H}, \mathrm{Cp}-\mathrm{H}), 3.93(\mathrm{~m}, 1 \mathrm{H}, \mathrm{Cp}-\mathrm{H}), 0.84(\mathrm{~s}, 9 \mathrm{H}, t-\mathrm{Bu}) .{ }^{13} \mathrm{C}$ NMR $\left(\mathrm{CDCl}_{3}\right): 149.9,145.5,127.4$ (2C), 127.1, 126.7, 126.5, 97.6, 79.2, 78.4, 72.4, 72.1, 70.9, 68.6, 47.5, 30.0.IR: 2958, 2927, 2862, 1458. HRMS Calcd for $\mathrm{C}_{27} \mathrm{H}_{28} \mathrm{FeS}$ : 440.1261. Found: 440.1304 .

(S)-1-t-Butylsulfanyl-2-phenylferrocene (5g). The general procedure was followed using ferrocene $4 \mathrm{~g}$ ( $8 \mathrm{mg}, 0.02 \mathrm{mmol})$, toluene $(1.5 \mathrm{~mL}), \mathrm{Et}_{3} \mathrm{~N}(29 \mu \mathrm{L}, 0.21 \mathrm{mmol})$ and $\mathrm{HSiCl}_{3}(32 \mu \mathrm{L}$, $0.32 \mathrm{mmol})$. Column chromatography using $n$-heptane/ethyl acetate (v/v: 100/0 then 95/5) afforded $5 \mathrm{~g}$ (7 mg, $0.02 \mathrm{mmol}, 91 \%)$ as an orange oil. 1H NMR (CDCl3): 7.78 (m, 2H, Ph), 7.31-7.23 (m, 3H, Ph), 4.59 (m, 1H, Cp-H), 4.46 (m, 1H, Cp-H), 4.37 (m, 1H, Cp-H), 4.13 (s, $5 \mathrm{H}, \mathrm{Cp}-\mathrm{H}), 0.97$ (s, 9H, t-Bu). ${ }^{13} \mathrm{C} \mathrm{NMR}\left(\mathrm{CDCl}_{3}\right)$ : 138.1, 129.9, 127.4, 126.3, 92.0, 77.9, 76.7, 
70.9, 68.7, 68.5, 46.3, 30.5. IR: 2924, 2852, 1643, 1462. HRMS Calcd for $\mathrm{C}_{20} \mathrm{H}_{22} \mathrm{FeS}: 350.0792$. Found: 350.1015 .

ortho-Lithiation of (R)-(+)- $\boldsymbol{N}, \boldsymbol{N}$-dimethyl-1-ferrocenylethylamine (3). ${ }^{44}$ To a solution of $(R)-(+)-N, N$-dimethyl-1-ferrocenylethylamine $3(0.38 \mathrm{mmol})$ in dry diethyl ether $(1 \mathrm{~mL})$ was added $n$-butyllithium $(0.43 \mathrm{mmol})$. The reaction mixture was heated to reflux for 3 hours before disulfide $(0.46 \mathrm{mmol})$ was added. After 20 hours refluxing, the mixture was cooled to room temperature. Water $(1 \mathrm{~mL})$ was added and the organic layer was washed with $\mathrm{H}_{2} \mathrm{O}(2 \times 2 \mathrm{~mL})$ and aqueous $\mathrm{H}_{3} \mathrm{PO}_{4}(3 \times 3 \mathrm{~mL}, 10 \%)$. The combined aqueous layers were extracted with $\mathrm{Et}_{2} \mathrm{O}$ $(3 \times 10 \mathrm{~mL})$ before neutralization with aqueous $\mathrm{NaOH}(2 \mathrm{M})$. After extraction with $\mathrm{Et}_{2} \mathrm{O}$ $(3 \times 20 \mathrm{~mL})$ and drying over $\mathrm{MgSO}_{4}$, the crude product was concentrated to dryness and purified.

$\left(\boldsymbol{S}_{\mathrm{Fc}}, \boldsymbol{R}\right)$-2-Dimethylaminoethyl-1-methylsulfanyl ferrocene (6a). [100113-94-8]. ${ }^{44}$ The general procedure was followed using $(R)-(+)-N, N$-dimethyl-1-ferrocenylethylamine 3 (98 mg, $0.38 \mathrm{mmol})$, diethyl ether $(1 \mathrm{~mL}), n$-BuLi $(310 \mu \mathrm{L}, 0.43 \mathrm{mmol}, 1.39 \mathrm{M}$ in hexanes $)$ and dimethyl disulfide $(41 \mu \mathrm{L}, 0.46 \mathrm{mmol})$. Crystallization from pentane afforded 6a $(24 \mathrm{mg}, 0.08 \mathrm{mmol}$, $21 \%)$ as an orange crystalline solid. ${ }^{1} \mathrm{H} \mathrm{NMR}\left(\mathrm{CDCl}_{3}\right): 4.32(\mathrm{~m}, 1 \mathrm{H}, \mathrm{Cp}-\mathrm{H}), 4.18(\mathrm{~m}, 1 \mathrm{H}, \mathrm{Cp}-\mathrm{H})$, 4.16 (m, 1H, Cp-H), 4.11 (m, 5H, Cp-H), 3.93 (q, 1H, J = 6.8 Hz, CH), 2.29 (s, 3H, S-Me), 2.13 (s, 6H, N-Me $), 1.40$ (d, 3H, $J=6.8 \mathrm{~Hz}, \mathrm{C}-\mathrm{Me}) .{ }^{13} \mathrm{C} \mathrm{NMR}\left(\mathrm{CDCl}_{3}\right): 91.8,83.4,71.1,70.0,67.2$, $66.5,56.2,40.4,19.8,13.2$.

$\left(\boldsymbol{S}_{\mathrm{Fc}}, \boldsymbol{R}\right)$-1-Cyclohexylsulfanyl-2-dimethylaminoethylferrocene $(\mathbf{6 b})$. The general procedure was followed using $(R)-(+)-N, N$-dimethyl-1-ferrocenylethylamine 3 (98 mg, $0.38 \mathrm{mmol}$ ), diethyl ether ( $1 \mathrm{~mL}), n$-BuLi $(295 \mu \mathrm{L}, 0.42 \mathrm{mmol}, 1.43 \mathrm{M}$ in hexanes) and dicyclohexyl disulfide $(110 \mu \mathrm{L}, 0.46 \mathrm{mmol})$. Column chromatography with Flashmaster Personal apparatus using $\mathrm{CH}_{2} \mathrm{Cl}_{2} / \mathrm{NH}_{4} \mathrm{OH}(\mathrm{v} / \mathrm{v} 98: 2)$ afforded $6 \mathbf{b}(53 \mathrm{mg}, 0.14 \mathrm{mmol}, 38 \%)$ as an orange solid. mp: 50-55 ${ }^{\circ} \mathrm{C} .{ }^{1} \mathrm{H}$ NMR $\left(\mathrm{CDCl}_{3}\right): 4.31$ (m, 1H, Cp-H), 4.20 (m, 1H, Cp-H), 4.16 (m, 1H, Cp-H), 4.09 (m, 5H, Cp-H), 3.97 (q, 1H, $J=6.9 \mathrm{~Hz}, \mathrm{CH}), 2.97$ (m, 1H, Cy), 2.12 (s, 6H, N-Me $)$, 1.92-1.11 (m, 10H, Cy), 1.33 (d, 3H, $J=6.8 \mathrm{~Hz}, \mathrm{C}-\mathrm{Me}) .{ }^{13} \mathrm{C} \mathrm{NMR}\left(\mathrm{CDCl}_{3}\right): 94.4,78.3,75.1,70.2,70.0$, 67.8, 66.7, 56.0, 47.8, 40.1, 34.2, 33.0, 26.4, 26.1, 25.9, 11.2. MS (EI) $\mathrm{m} / \mathrm{z}(\%): 371\left(85, \mathrm{M}^{+\bullet}\right)$, $326\left(53,\left[\mathrm{M}-\mathrm{NMe}_{2}\right]^{+}\right)$. IR: 2968, 2850, 2772, 1686, 1654, 1560, 1544, 1362, 1262, 1190, 1096, 1060. HRMS Calcd for $\mathrm{C}_{20} \mathrm{H}_{29}$ FeNS: 371.1370 . Found: 371.1346 .

\section{Benzylidene transfer to benzaldehyde. General procedure}

To a solution of sulfide $(0.05 \mathrm{mmol})$ in $t-\mathrm{BuOH} / \mathrm{H}_{2} \mathrm{O} 9 / 1(415 \mu \mathrm{L})$ were added benzyl bromide $(60 \mu \mathrm{L}, 0.50 \mathrm{mmol}), \mathrm{NaI}(38 \mathrm{mg}, 0.25 \mathrm{mmol})$, benzaldehyde $(25 \mu \mathrm{L}, 0.25 \mathrm{mmol})$ and $\mathrm{NaOH}$ (20 mg, $0.50 \mathrm{mmol})$. The reaction mixture was stirred at room temperature and monitored by TLC using $n$-heptane/ethyl acetate (v/v 9:1). Water (1 mL) was then added and the aqueous phase was extracted with dichloromethane $(3 \times 2 \mathrm{~mL})$. The combined organic phases were dried over $\mathrm{MgSO}_{4}$ and concentrated to dryness. Column chromatography using $n$-heptane/ethyl acetate afforded stilbene oxide 8. ${ }^{1} \mathrm{H}$ NMR $\left(\mathrm{CDCl}_{3}\right)$ : 7.42-7.17 (m, $2 \times 10 \mathrm{H}, \mathrm{Ph}$, cis and trans), $4.36(\mathrm{~s}$, $2 \mathrm{H}, \mathrm{CHO}$, cis), 3.87 (s, 2H, CHO, trans). ${ }^{13} \mathrm{C} \mathrm{NMR}\left(\mathrm{CDCl}_{3}\right): 137.0$ (trans), 134.3 (cis), 128.5 
(trans), 128.3 (trans), 127.8 (cis), 127.4 (cis), 126.9 (cis), 125.4 (trans), 62.8 (trans), 59.8 (cis). HPLC: Daicel Chiralpak AD-H column $250 \times 4.6$ (L × I.D.) $5 \mu \mathrm{m}, n$-hexane/i-PrOH (v/v 90/10) at $1 \mathrm{~mL} \cdot \mathrm{min}^{-1}, 228 \mathrm{~nm}, 20^{\circ} \mathrm{C} .2 .45 \mathrm{~min}(R, R), 7.51 \mathrm{~min}(S, S)$.

\section{Acknowledgements}

We gratefully acknowledge the "PunchOrga" Network (Pôle Universitaire Normand de Chimie Organique), the "Ministère de la Recherche", CNRS (Centre National de la Recherche Scientifique), the "Région Basse-Normandie" and the European Union (FEDER funding) for financial support. We also thank warmly Dr Jean-François Brière (Caen), Prof. Serge Piettre and Dr Isabelle Chataigner (Rouen) for fruitful discussions and collaboration.

\section{References}

1. Rouhi, A. M. Chem. Eng. News 2004, 82 (24), 47.

2. Tye, H.; Comina, P. J. J. Chem. Soc., Perkin Trans. 1 2001, 1729.

3. Blaser, H.-U. Chem. Commun. 2003, 293.

4. Blaser, H. U.; Schmidt, E. Asymmetric Catalysis on Industrial Scale: Challenges, Approaches and Solutions; Wiley-VCH: Weinheim, 2004.

5. Breuer, M.; Ditrich, K.; Habicher, T.; Hauer, B.; Kesseler, M.; Stürmer, R.; Zelinski, T. Angew. Chem., Int. Ed. 2004, 43, 788.

6. Mikami, K.; Terada, M.; Korenaga, T.; Matsumoto, Y.; Ueki, M.; Angelaud, R. Angew. Chem. Int. Ed. 2000, 39, 3532.

7. Ojima, I. Catalytic Asymmetric Synthesis; Wiley: New York, 2000.

8. Dalko, P. I.; Moisan, L. Angew. Chem., Int. Ed. 2001, 40, 3726.

9. Dalko, P. I.; Moisan, L. Angew. Chem., Int. Ed. 2004, 43, 5138.

10. Li, A.-H.; Dai, L.-X.; Aggarwal, V. K. Chem. Rev. 1997, 97, 2341.

11. Aggarwal, V. K.; Winn, C. L. Acc. Chem. Res. 2004, 8, 611.

12. Aggarwal, V. K.; Richardson, J. Chem. Commun. 2003, 2644.

13. Julienne, K.; Metzner, P.; Henryon, V.; Greiner, A. J. Org. Chem. 1998, 63, 4532.

14. Julienne, K.; Metzner, P.; Henryon, V. J. Chem. Soc., Perkin Trans. 1 1999, 731.

15. Zanardi, J.; Leriverend, C.; Aubert, D.; Julienne, K.; Metzner, P. J. Org. Chem. 2001, 66, 5620.

16. Takada, H.; Metzner, P.; Philouze, C. Chem. Commun. 2001, 2350.

17. Zanardi, J.; Lamazure, D.; Minière, S.; Reboul, V.; Metzner, P. J. Org. Chem. 2002, 67, 9083.

18. Minière, S.; Reboul, V.; Arrayás, R. G.; Metzner, P.; Carretero, J. C. Synthesis 2003, 2249. 
19. Minière, S.; Reboul, V.; Metzner, P.; Fochi, M.; Bonini, B. F. Tetrahedron: Asymmetry 2004, 15, 3275.

20. Alayrac, C.; Nowaczyk, S.; Lemarié, M.; Metzner, P. Synthesis 1999, 669.

21. Nowaczyk, S.; Alayrac, C.; Reboul, V.; Metzner, P.; Averbuch-Pouchot, M.-T. J. Org. Chem. 2001, 66, 7841.

22. Fernandez, I.; Khiar, N.; Llera, J. M.; Alcudia, F. J. Org. Chem. 1992, 57, 6789.

23. Khiar, N.; Fernandez, I.; Alcudia, A.; Alcudia, F. Advances in Sulfur Chemistry; Rayner, C. Ed.; JAI Press: Greenwich-Connecticut, 2000; Vol. 2, pp 57-115.

24. Durst, T.; LeBelle, M. J.; Van den Eltzen, R.; Tin, K.-C. Can. J. Chem. 1974, 52, 761.

25. Rebière, F.; Riant, O.; Ricard, L.; Kagan, H. B. Angew. Chem., Int. Ed. 1993, 32, 568.

26. Priego, J.; Mancheño, O. G.; Cabrera, S.; Carretero, J. C. Chem. Commun. 2001, 2026.

27. Priego, J.; Mancheño, O. G.; Cabrera, S.; Carretero, J. C. J. Org. Chem. 2002, 67, 1346.

28. Weix, D. J.; Ellman, J. A. Org. Lett. 2003, 5, 1317.

29. Ellman, J. A.; Owens, T. D.; Tang, T. P. Acc. Chem. Res. 2002, 35, 984.

30. Sanders, R.; Mueller-Westerhoff, U. T. J. Organomet. Chem. 1996, 512, 219.

31. Cotton, H. K.; Huerta, F. F.; Bäckvall, J.-E. Eur. J. Org. Chem. 2003, 2756.

32. Marquading, D.; Klusacek, H.; Gokel, G. W.; Hoffmann, P.; Ugi, I. K. J. Am. Chem. Soc. 1970, 92, 5389.

33. Gokel, G. W.; Ugi, I. K. J. Chem. Educ. 1972, 49, 294.

34. Jensen, J. F.; Søtofte, I.; Sørensen, H. O.; Johannsen, M. J. Org. Chem. 2003, 68, 1258.

35. Farina, V.; Kapadia, S.; Krishnan, B.; Wang, C.; Liebeskind, L. S. J. Org. Chem. 1994, 59, 5905.

36. Song, Z. J.; King, A. O.; Waters, M. S.; Lang, F.; Zewge, D.; Bio, M.; Jr., J. L. L.; Javadi, G.; Kassim, A.; Tschaen, D. M.; Reamer, R. A.; Rosner, T.; Chilenski, J. R.; Mathre, D. J.; Volante, R. P.; Tillyer, R. Proc. Nalt. Acad. Sci. U. S. 2004, 101, 5776.

37. Akiba, K.-Y.; Takee, K.; Shimizu, Y.; Ohkata, K. J. Am. Chem. Soc. 1986, 108, 6320.

38. Ohara, Y.; Akiba, K.-Y.; Inamoto, N. Bull. Chem. Soc. Jpn 1983, 1983, 1508.

39. Mancheño, O. G.; Priego, J.; Cabrera, S.; Arrayás, R. G.; Llamas, T.; Carretero, J. C. J. Org. Chem. 2003, 68, 3679.

40. Cabrera, S.; Arrayás, R. G.; Carretero, J. C. J. Am. Chem. Soc. 2004, 43, 3944.

41. Mancheño, O. G.; Arrayás, R. G.; Carretero, J. C. J. Am. Chem. Soc. 2004, 126, 456.

42. Aggarwal, V. K.; Calamai, S.; Ford, G. J. J. Chem. Soc., Perkin Trans. 1 1997, 593.

43. Priego, J.; Mancheño, O. G.; Cabrera, S.; Arrayás, R. G.; Llamas, T.; Carretero, J. C. Chem. Commun. 2002, 2512.

44. Herrmann, R.; Hübener, G.; Ugi, I. Tetrahedron 1985, 40, 941. 